\title{
Patent Pooling for Promoting Access to Antiretroviral Drugs (ARVs) - A Strategic Option for India
}

\author{
Kanikaram Satyanarayana* and Sadhana Srivastava
}

Intellectual Property Rights Unit, Indian Council of Medical Research, Department of Health Research, Ansari Nagar, New Delhi 110029, India

\begin{abstract}
The current HIV/AIDS scenario in India is quite grim with an estimated 2.4 million people living with HIV/AIDS (PLHA) in 2008, just behind South Africa and Nigeria. The anti-retroviral drugs (ARVs) remain the main stay of global HIV/AIDS treatment. Over 30 ARVs (single and FDCs) available under six categories viz., NRTIs (nucleoside reverse transcriptase inhibitors), NNRTIs (non-nucleoside reverse transcriptase inhibitors), Protease inhibitors, the new Fusion inhibitors, Entry inhibitors-CCR5 co-receptor antagonists and HIV integrase strand transfer inhibitors. The major originator companies for these ARVs are: Abbott, Boehringer Ingelheim (BI), Bristol-Myers Squibb (BMS), Gilead, GlaxoSmithKline (GSK), Merck, Pfizer, Roche, and Tibotec. Beginning with zidovidine in 1987, all the drugs are available in the developed countries. In India, about 30 ARVs are available as generics manufactured by Aurobindo, Hyderabad, Andhra Pradesh; Cipla Limited, Goa; Emcure Pharmaceuticals, Pune, Maharashtra; Hetero Drugs, Hyderabad, Andhra Pradesh; Macleods Pharmaceuticals, Daman; Matrix Laboratories, Nashik, Maharashtra; Ranbaxy, Sirmour, Himachal Pradesh; and Strides Arcolab, Bangalore, Karnataka. The National AIDS Control Organization (NACO) set up in 1992 by the Govt. of India provides free ARVs to HIV positive patients in India since 2004. The drugs available in India include both single drugs and FDCs covering both first line and second line ARVs. Even while there are claims of stabilization of the disease load, there is still huge gap of those who require ARVs as only about 150,000 PLHA receive the ARVs from the Govt. and other sources. Access to ARVs therefore is still a cause of serious concern ever since India became fully Trade Related Aspects of Intellectual Property Rights (TRIPS)-complaint in 2005. Therefore, the Indian pharmaceutical companies cannot make generics for those for drugs introduced post-2005 due to product patent regime. Other concerns include heat stable, other better formulations and second line ARVs for adults and more drugs and formulations for paediatric groups, that are still to be widely available in India and other developing countries. To examine whether strong intellectual property (IP) protection systems are to be considered important barriers for the limited or lack of access to ARVs, we studied the patent profile of the ARVs of the originator companies within and outside India. We could record 93 patents in the United States Patent \& Trademark Office (USPTO). The originator companies have been also aggressively filing and enforcing patents in India. There have been a few efforts by companies like Gilead and GSK to grant licenses to generic manufacturers in developing countries, ostensibly to promote access to ARVs through lower (two-tier) pricing. These steps are considered as too little and too late. There is an urgent need to look for alternative strategies to promote access to ARVs both linked to and independent of IPRs. Patent pooling as a viable strategy mooted by the UNITAID should be seriously explored to promote access to ARVs. India is ideally suited for trying out the patent pool strategy as most of the global requirement of affordable ARV drugs for HIV/AIDS treatment is sourced from Indian generic companies.
\end{abstract}

\section{INTRODUCTION}

India is one of the largest and most populated countries in the world, with over a billion inhabitants. There are currently an estimated 2.4 million Indians living with HIV/AIDS [1]. Although HIV infection emerged as late as 1986 in India, later than it did in many other countries, the infection rates rose sharply throughout the 1990s. In 1987 the Government of India launched a National AIDS Control Programme (NACP) to co-ordinate national responses which covered surveillance, blood screening, and health education [2]. By the end of 1987 , of the 52,907 people tested, 135 people were found to be HIV positive and 14 had AIDS.

*Address correspondence to this author at the Intellectual Property Rights Unit, Indian Council of Medical Research, Department of Health Research, Ansari Nagar, New Delhi 110029, India;

E-mails: kanikaram_s@yahoo.com, satyanarayanak@icmr.org.in
Most of these initial cases had occurred through heterosexual sex. But at the end of the 1980s a rapid spread of HIV was observed among injecting drug users in Manipur, Mizoram and Nagaland - three north-eastern states of India bordering Myanmar (Burma). At the beginning of the 1990s, as infection rates continued to rise, responses were proportionately strengthened. In 1992, the Government of India set up the National AIDS Control Organisation (NACO), to oversee the formulation of policies, prevention work and control programmes relating to HIV and AIDS [2]. In the same year, the Government of India launched a Strategic Plan for HIV prevention. This plan established the administrative and technical basis for programme management and also set up State AIDS bodies in 25 states and 7 union territories [3]. It was able to make a number of important improvements in HIV prevention such as improving blood safety etc. [3]. 
It is now clear that although individual states and cities in India had separate epidemics, HIV had spread to the general population by the 1990s. Currently, the epidemic affects all sectors of Indian society, even those initially considered not at risk [4].

\section{TREATMENT FOR PEOPLE LIVING WITH HIV}

Antiretroviral drugs (ARVs), which can significantly delay the progression from HIV to AIDS - have been available in developed countries since 1996 [5]. There are currently over 30 ARVs available globally [6]. These include largely NRTIs, NNRTIs, Protease inhibitors, the new Fusion inhibitors, Entry inhibitors-CCR5 co-receptor antagonists and HIV integrase strand transfer inhibitors - both single drugs and fixed dose combinations (FDCs) (Table 1). The major originator companies include: Abbott, Boehringer Ingelheim (BI), Bristol-Myers Squibb (BMS), Gilead, GlaxoSmithKline (GSK), Merck, Pfizer, Roche, and Tibotec

Table 1. Total Antiretroviral Drugs Available

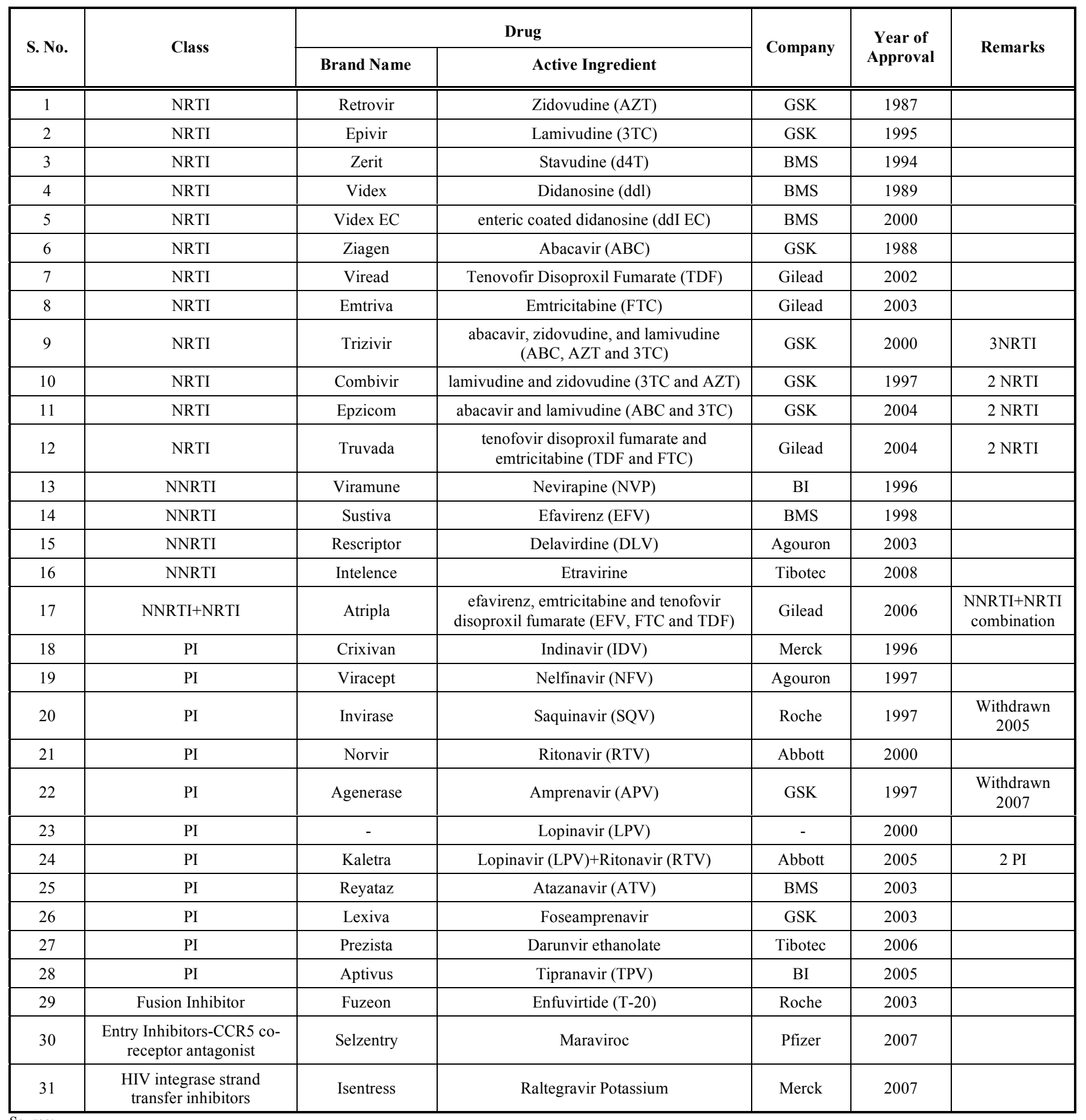

Source:

1. HIV prevelance datalUSFDA Approved HIV AIDS Drug updated 14/05/2009

2. Electronic Orange Book updated Feb, 2009 
[7]. The availability of ARV drugs began in 1987 with the zidovidine and the latest ones to be approved in 2007 are the Maraviroc [8] and Raltegravir [9] potassium marketed as Selzentry (Pfizer) and Isentress (Merck) respectively.

There are about 30 ARV drugs available in India (Table 2). Data show that almost all classes of drugs are manufactured and sold by the generic manufacturers viz., Aurobindo, Hyderabad, Andhra Pradesh; Cipla Limited, Verna Industrial Estate, Goa; Emcure Pharmaceuticals, Pune, Maharashtra; Hetero Drugs, Hyderabad, Andhra Pradesh; Macleods Pharmaceuticals, Kachigam, Daman; Matrix Laboratories, Nashik, Maharashtra; Ranbaxy, Sirmour, Himachal Pradesh; and Strides Arcolab, Anekal Taluk, Bangalore.

The drugs available in India thus include both single drug and FDCs covering both the first line and second line ARVs [10-12]. The Government of India launched the free antiretroviral treatment (ART) programme in 2004, starting with eight tertiary-level government hospitals in the six highprevalence states of India [3]. All persons with HIV infection who are clinically eligible to receive ART are included in the Phase I of the programme. The subgroups of the people living with HIV/AIDS (PLHA) targeted on a priority basis include: (i) sero-positive mothers who have participated in the prevention of parent-to-child transmission (PPTCT) programme; (ii) sero-positive children below the age of 15 years; and (iii) people with AIDS who seek treatment in government hospitals [3]. The free ART programme envisages a comprehensive prevention, care and treatment programme, with i) standardized, simplified combination of ART regimens; ii) regular secure supply of good-quality ARV drugs; and iii) a robust monitoring and evaluation system eventually working towards universal access to care and treatment [3].

Linkages and referrals to other programmes as the prevention of parent-to-child transmission (PPTCT), programme are also being strengthened to enable women and children living with HIV/AIDS have greater access to treatment. The Phase I programme is also establishing linkages with other related national programmes as the Revised National Tuberculosis Control Programme (RNTCP), Reproductive and Child Health (RCH) Programme and the massive National Rural Health Mission (NRHM) [3].

\section{ACCESS TO ARVs IN INDIA}

Currently there are over 160 ART ARV centers in 31 States and Union Territories [6] with an estimated 140,000 patients are receiving ARVs free of cost at these centers [13]. Another 35,000 patients are receiving free ARVs at ART centers run by NGOs and other organizations [3]. The ART centres are being scaled up in a phased manner to provide free ARVs to 100,000 patients by the end of 2007 and 300,000 patients by 2011 in 250 centres across India under phase III of NACO [13]. ARV drugs including combination containing ingredients for adults are: i) Two drug combination tablets containing Stavudine and Lamivudine; ii) Two drugs combination tablets containing Zidovudine and Lamivudine; iii) Three drugs combination tablets containing Stavudine, Lamivudine and Nevirapine; iv) Three drug combination tablets containing Zidovudine, Lamivudine and Nevirapine; v) Efavirenz [3]. The following drugs are used for pediatric HIV management for children weighing up to $20 \mathrm{~kg}$ : FDCs i) Stavudine and Lamivudine; ii) Stavudine and Lamivudine; iii) Stavudine, Lamivudine and Nevarapine; iv) Stavudine, Lamivudine and Nevarapine; and v) Efavirenz [4]. But some drugs are still not available in India as single drugs, as per our analysis (Table 3). These include four protease inhibitors (Agenerase, Aptivus, Lexiva, and Prezista), one NNRTI (Rescriptor) and one Fusion inhibitor (Fuzeon) [7, 14].

Thus, only about 150,000 people with HIV/AIDS access the ARVs from the public sector while some also get these through private health facilities, which dominate India's healthcare sector. But the vast majority of 2.4 million PLHA cannot afford to buy treatment privately. While the coverage of treatment continues to remain unacceptably low, improvements are being made to expand access to ARVs in a number of areas [15]. This is a massive challenge for the NACO, Govt. of India.

The HIV/AIDS is a chronic disease requiring lifelong treatment with different ARV combinations compounding the problem for people who also develop drug resistance and side effects over time [16]. Thus, increasing access to ARVs also means that an increasing number of people living with HIV in India are likely to develop resistance to the first line treatment necessitating switching over to the second line ARVs. Data from Africa show that over a five year period $22 \%$ people needed such a switch-over [16]. In addition, another study from South Africa found that within 3 years on ART, $21 \%$ of patients who had started a d4T-based regimen needed to be switched because of toxicity [17]. This resulted in a 2006 recommendation by the WHO to move away from $\mathrm{d} 4 \mathrm{~T}$ to less toxic combinations based on either AZT or tenofovir [18], of course with a significant price implications. In 2008, the NACO began to roll out government funded second-line anti-retroviral treatment in two centres in Mumbai and Chennai [6]. There are also plans to improve the provision of nevirapine to pregnant mothers with HIV, which can significantly reduce the risk that they will pass infection on to their child [6]. In common with other parts of the developing world, the second line ARV treatment in India is currently prohibitively more expensive than the first line treatment which is essentially based on the generics.

Despite several global initiatives to provide ARV treatment in poor and middle income countries, like the 3 by 5 and the current efforts towards Universal Access, the outreach is still poor with the targets well behind with coverage of an estimated 3 million or about $31 \%$ of the 9.7 million needing the ARVs $[15,16]$. What is more, about 2.5 million new infections were added during 2007 underscoring the massive task ahead. Another matter of serious concern is the estimated 2.1 million children under 15 years needing 
Table 2. Antiretroviral Drugs Available in India

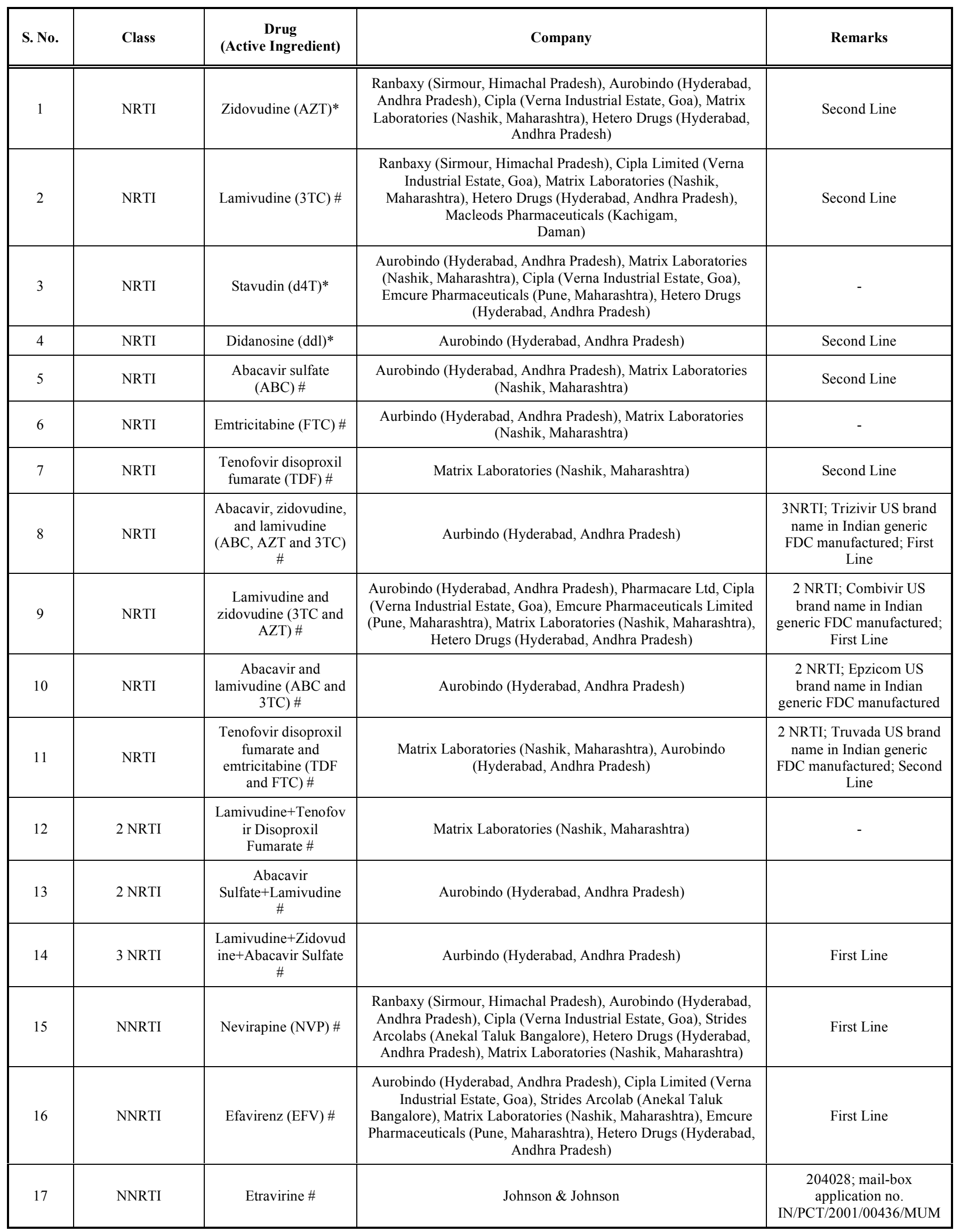




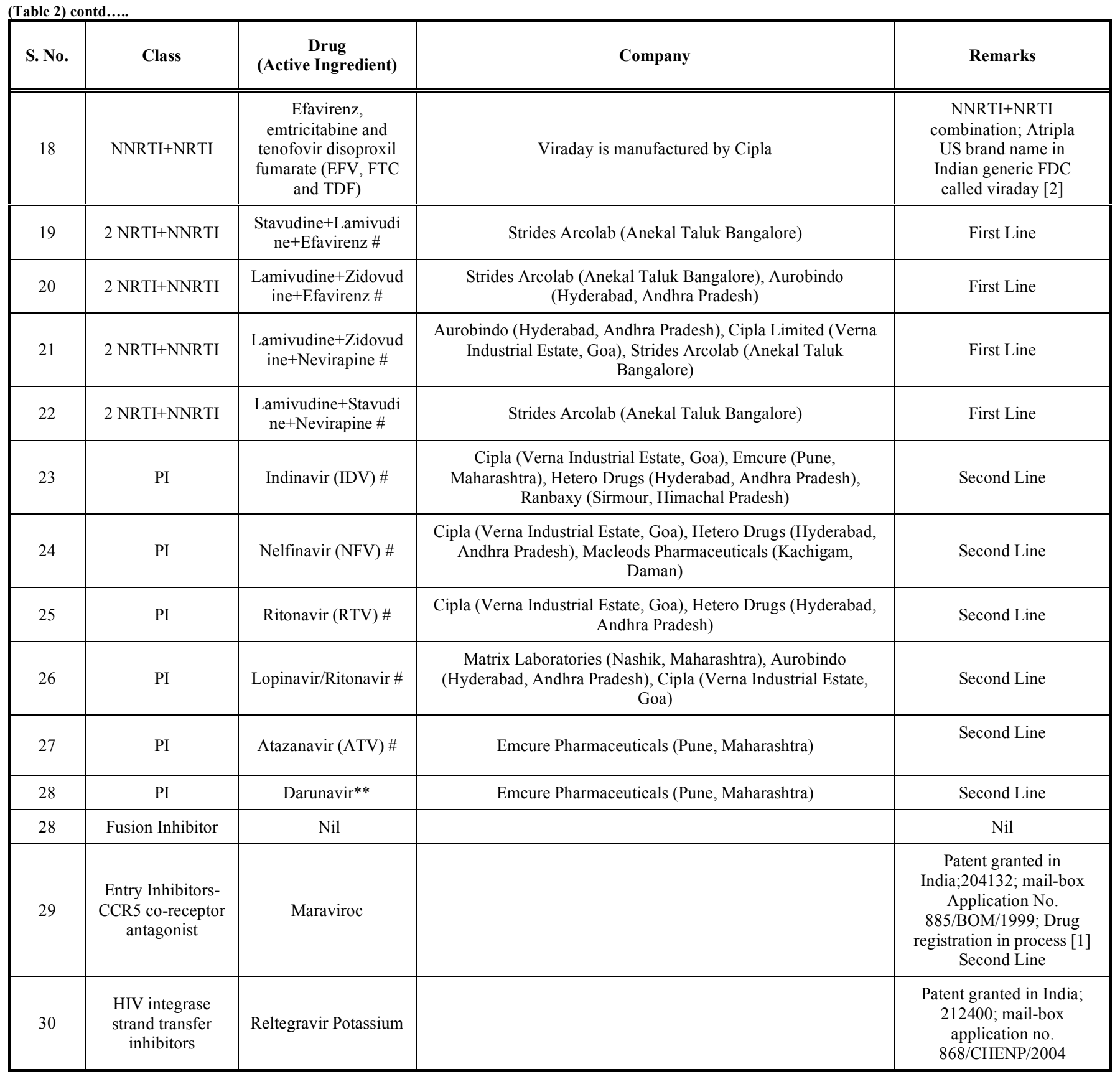

Approved Drugs; \# Tentatively Approved.

** Registration pending with the Indian Drug Controller.

Explanation for classifying drugs (active ingredient) as First Line \& Second Line

single drug- First Line- National AIDS Control Organization (NACO); National Program.

single drug- Second Line- Prioritizing Second-Line Antiretroviral Drugs for Adults and Adolescents: A Public Health Approach.

FDC- First Line- NACO+WHO guidelines.

FDC- Second Line- WHO guidelines.

Source:

1. www.jipmer.edu/charu/v4issue1.pdf

2. http://pharmacy.around-world.biz/drugs/Atripla.html

3. USFDA: HIV prevalence data President's Emergency Plan for AIDS Relief updated 14/05/2009.

4. Prioritizing Second-Line Antiretroviral Drugs for Adults and Adolescents: a Public Health Approach (First \& Second Line).

treatment while the coverage is about $10 \%$ only [15]. Funding for the purchase of the drugs remains a serious constraint with the gap between required and available resources of US\$8.1 billion during 2007. To meet the universal targets, funding needs to be enhanced to at least four times to US\$ 35 billion in 2010 and to US\$41 billion in
2015 [15]. One critical factor continues to be the cost of ARVs [15].

\section{IMPACT OF NEW PATENT REGIMES}

In the light of the new TRIPS-complaint IP regime [19] in India and other developing countries and the need to find 
Table 3. ART Drugs Not Available in India as Single Drug

\begin{tabular}{|c|c|c|c|c|c|c|}
\hline S. No. & $\begin{array}{c}\text { Brand } \\
\text { Name }\end{array}$ & Class & Generic & $\begin{array}{c}\text { Company } \\
\text { Manufacturing }\end{array}$ & Applicant & Assignee \\
\hline \hline 1 & Rescriptor & NNRTI & Delavirdine (DLV) & Agouron (USA) & Pfizer (USA) & Pharmacia \& Upjohn Co \\
\hline 2 & Agenerase & PI & Amprenavir (APV) & GSK (UK) & GSK (UK) & Vertex Pharma GSK \\
\hline 3 & Aptivus & PI & Tipranavir (TPV) & BI (Germany) & BI (Germany) & $\begin{array}{c}\text { Pharmacia and } \\
\text { Upjohn Co. }\end{array}$ \\
\hline 4 & Lexiva & PI & Fosamprenavir Calcium (FOS-APV) & GSK (UK) & GSK (UK) & Vertex Pharmaceuticals \\
\hline 5 & Prezista* & PI & Darunavir Ethanolate & Tibotec (USA), & Tibotec (USA) & Tibotec (USA) \\
\hline 6 & Fuzeon & Fusion Inhibitor & Enfuvirtide (T-20) & Roche (Switzerland) & $\begin{array}{c}\text { Roche } \\
\text { (Switzerland) }\end{array}$ & $\begin{array}{c}\text { Duke University } \\
\text { Trimeris Inc. }\end{array}$ \\
\hline
\end{tabular}

Source:

1. HIV prevalence data/USFDA Approved HIV AIDS Drug Updated January 2008

2. Electronic Orange Book.

3. United States Patent \& Trade Mark Office.

*Registration pending with the Indian Drug Controller.

innovative strategies to provide ARVs, there is a need to have a serious look at whether the strong IP protection system is a barrier. We therefore looked at the patent profile of ARV drugs both in India and the USPTO filed by the originator companies. Table 4 shows data on the patent profile of FDA approved ARVs. We could track 93 patents on ARVs filed in the USPTO by the originator companies. The major patent filers were Abbot, Gilead, Abbott, GSK etc. with the number of patents filed varying with the drug. For example, Abbott filed as many as 20 patents on Lopinavir-Ritonavir (sold as Kaletra). For combinations as Atripla (Efavirenz and Emtricitabine and Tenofovir Disoproxil fumerate), Gilead filed as many as 15 patents. Similarly, Gilead also filed 10 patents on Truvada (Emtricitabine and Tenofovir Disoproxil fumarate). Data on break-up of the patents filed at the USPTO show that Gilead holds the maximum (25) patents followed by Abbott with 20, GSK with 17, Tibotec 5 etc., (Table 5).

Significantly, most generic antiretroviral agents currently now being used in Africa and Asia are manufactured in India as the Indian Patent Act (1970) permitted making generic copies of drugs in India [20]. With the largest global standard facilities for manufacturing outside the USA, the Indian companies were able to offer HIV drugs at a fraction of the cost of brand-name drugs. The new Indian patent Act (2005) has already created significant barriers for the development of new generics on ARVs patented in India after 2005 [21]. Developing countries had to allow inventors to file patent applications from January 1, 1995, and the decision on whether or not to grant any patent could be taken at the end of the transition period. This has potentially serious impact on global initiatives of MSF, PEPFAR, Clinton Foundation etc which source drugs from the Indian companies for distribution in African countries [20].

There are also apprehensions that the first-line antiretroviral drug regimens in wide use may soon be found wanting to meet the needs of HIV-infected patients [22]. There is also evidence to show that some people may be intolerant to some drugs as also reports of contraindications that need attention $[18,23]$. More importantly, there could be treatment failure necessitating drugs outside the available ARV drug regimens. In addition, without strong second-line therapeutic regimens HIV patients could well stand to lose the benefits of antiretroviral therapy. Worse still, they may transmit the drug-resistant virus to others compounding the problem. "Sustaining" may well soon surpass with "scaling up" of antiretroviral therapy emerging as the major challenge [22]. Brazil is already facing this challenge, and African and Asian countries with far fewer resources will probably encounter even greater hurdles in gaining access to secondline therapies [22].

The impact of Trade Related Aspects of Intellectual Property Rights (TRIPs)-complaint legislation [19, 21] on access to ARVs to HIV-infected persons in resource-limited countries therefore cannot be overemphasized. There is a need to find solutions and find them fast. A dual approach may be required i) ensure the continued availability of high quality generics by manufacturers from India and elsewhere; and ii) encourage strong efforts towards developing new generics from patented drugs and new formulations through newer global strategies. For example, the US FDA has approved, under PEPFAR, several generic antiretroviral preparations for purchase and use outside the United States [10].

There have been a few attempts by the originator companies, under intense criticism on their pricing policies, to license the ARV drugs. Table 6 shows data on licensing of ARV drugs by the originator companies to non-US companies, mostly in South Africa, other African countries and India. GSK has licensed to maximum companies outside the US - 4 companies in the African continent. The BMS has licensed its drugs stavudine and didanosine to over 49 countries including India. Some companies like Gilead have licensed manufacture of its drugs to a large number of generic companies in India through non-exclusive licensing [24]. 
Table 4. Patent Profile of FDA Approved Drugs

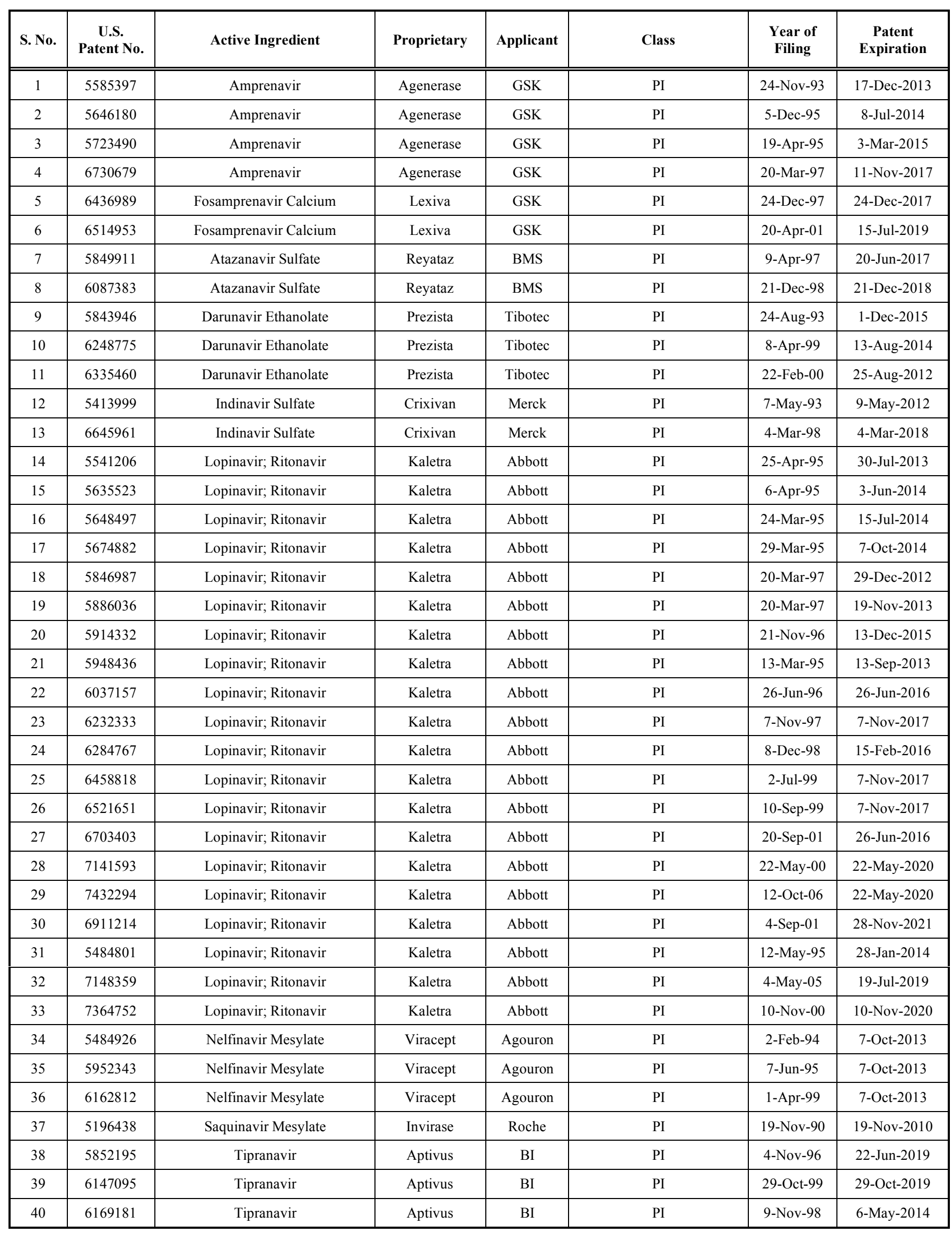




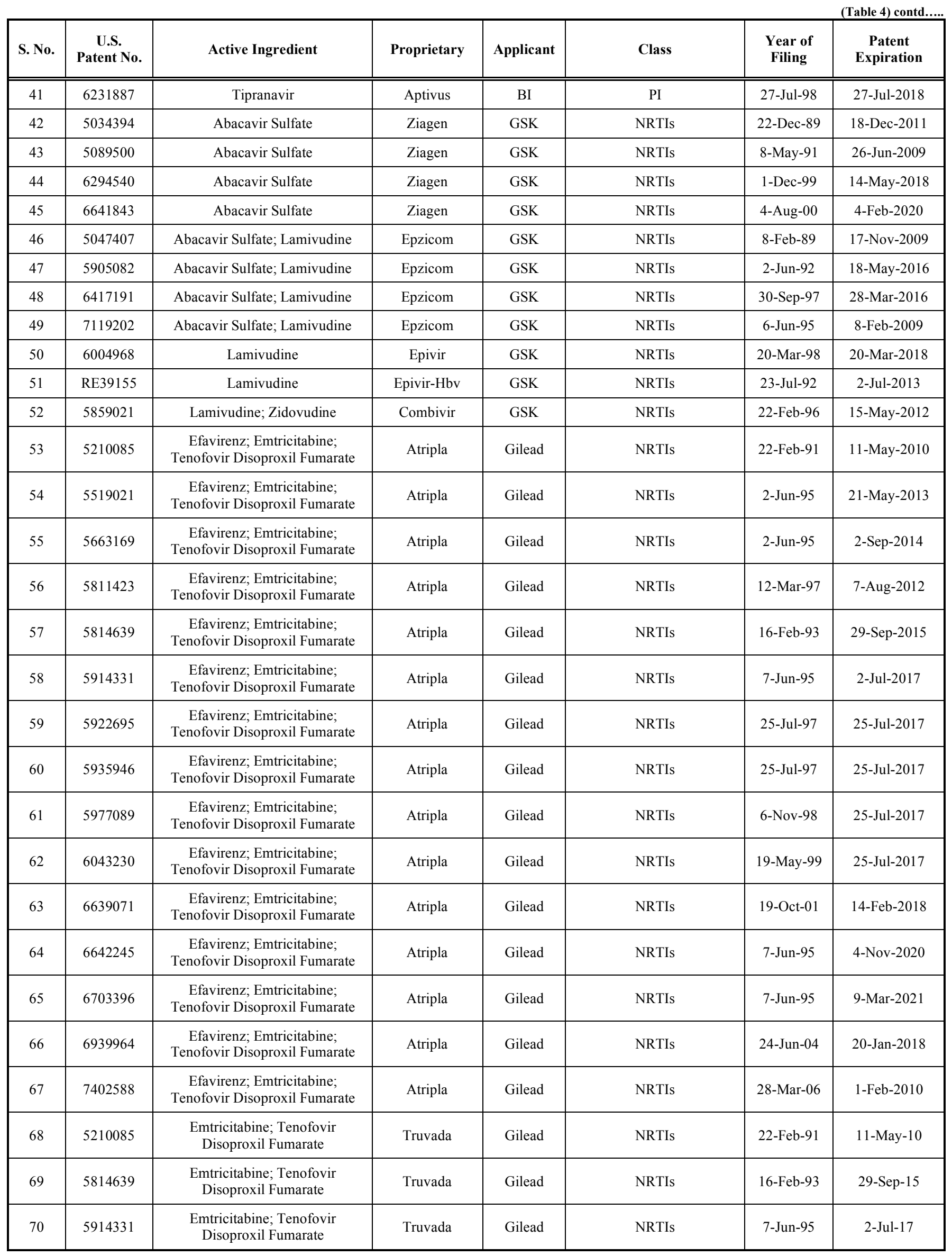




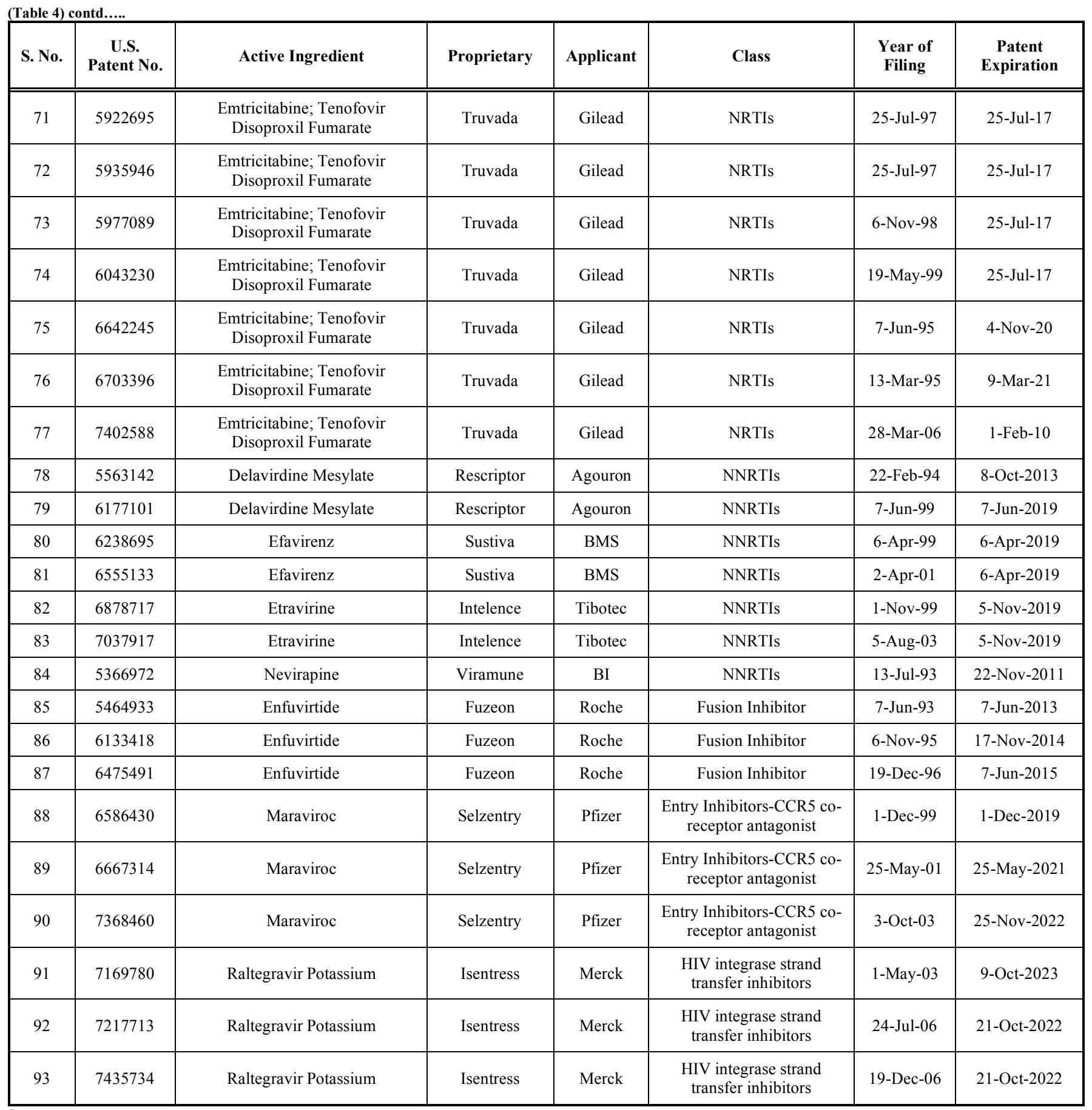

Souce:

Electronic Orange Book updated Feb, 2009

\section{OPTIONS TO PROMOTE ACCESS TO NEWER ARVS}

A priority now is to, among others, find less toxic firstline ARV combinations and drug options when resistance is developed [23]. The primary issue continues to be strong TRIPS-complaint global patenting regimes which impact the key generics-producing countries such as India, Brazil, and Thailand. The MSF estimates that the ARV prices are unlikely to see the dramatic $99 \%$ drop seen for the currently used first-line ARVs - from $>\$ 10,000$ per patient per year in 2000 to $\$ 87$ today [16]. National Governments of developing countries will therefore have difficult choices before them like whether to treat more number of patients on more affordable ARV combinations, or fewer people on less toxic but more expensive combinations.

Simple switching over from the most commonly used d4T-based first-line ARV combination to a less toxic option involves about twice the cost [23]. And changing over to a TDF-based ARV regimen would mean a 4-11 fold price increase [23]. According to MSF's estimates, replacing d4T with a TDF-based regimen for all patients from 2008 to 2014 
Table 5. Summary of US Patents on FDA Approved ART Drugs Company Wise

\begin{tabular}{|c|c|c|c|c|}
\hline S. No. & Company & No. of Patents & Name of the Drug & Class \\
\hline 1 & GSK & 4 & Agenerase & PI \\
\hline 2 & GSK & 2 & Lexiva & PI \\
\hline 3 & GSK & 4 & Ziagen & NRTIs \\
\hline 4 & GSK & 4 & Epzicom & NRTIs \\
\hline 5 & GSK & 2 & Epivir & NRTIs \\
\hline 6 & GSK & 1 & Combivir & NRTIs \\
\hline 7 & BMS & 2 & Reyataz & PI \\
\hline 8 & BMS & 2 & Sustiva & NNRTIs \\
\hline 9 & Tibotec & 3 & Prezista & PI \\
\hline 10 & Tibotec & 2 & Intelence & NNRTIs \\
\hline 11 & Merck & 3 & Isentress & HIV integrase strand transfer inhibitors \\
\hline 12 & Merck & 2 & Crixivan & PI \\
\hline 13 & Abbott & 20 & Kaletra & PI \\
\hline 14 & Agouron & 3 & Viracept & PI \\
\hline 15 & Agouron & 2 & Rescriptor & NNRTIs \\
\hline 16 & Roche & 1 & Invirase & PI \\
\hline 17 & Roche & 3 & Fuzeon & Fusion Inhibitor \\
\hline 18 & BI & 4 & Aptivus & PI \\
\hline 19 & BI & 1 & Viramune & NNRTIs \\
\hline 20 & Gilead & 15 & Atripla & NRTIs \\
\hline 21 & Gilead & 10 & Truvada & NRTIs \\
\hline 22 & Pfizer & 3 & Selzentry & Entry Inhibitors-CCR5 co-receptor antagonist \\
\hline \multicolumn{2}{|c|}{ Total } & \multicolumn{3}{|c|}{93} \\
\hline
\end{tabular}

Souce:

Electronic Orange Book updated Feb, 2009

(based on today's prices) would mean a 4-11 fold price increase $[16,25]$. Unless there are overall price reductions the overall increase of cost for ARVs. in some middle-income countries could be as high as 17-fold [16].

Besides the availability of generics for the first-line ARVs in countries with manufacturing capacity like India, Brazil, and Thailand, multiple producers and the resultant competition has actually brought down prices dramatically [16]. Globally, India is considered the "pharmacy of the developing world," as charities like MSF source over $80 \%$ of its ARVs from India as also other ARV providers like the Clinton Foundation, PEPFAR etc. [16, 20]. This was possible only because the pre-TRIPS patent regimes allowed the development of single drugs and FDCs, an innovation that not just simplified HIV/AIDS treatment but helped significant scale-ups. In the recent years, there have been aggressive patenting by originator companies in countries like India, Brazil and Thailand [26-28].

The global battle for affordable ARVs, thus is likely to get tougher in future. Developing countries with significant PLHA need to use all the means available including public health safeguards and flexibilities enshrined in the WTO TRIPS as reiterated in the Doha Declaration [29] that allows countries to overcome patent barriers by issuing compulsory licenses (CLs) to open the market to competition despite patent protection.

Other options open to sovereign countries include design or interpret national patent laws to limit the scope of patentability of new chemical entities with a public health priority and other strategies [30, 31]. Like, for example, the Indian Patents Act (2005) that allows pre-grant opposition [32]. In June 2008 such an opposition was successfully contested in India for the pediatric syrup formulation of NVP as the Indian patent office rejected the patent [26-28].

\section{PATENT POOLS}

In what is considered a path-breaking development, the UNITAID decided in principle in July 2008 to establish a patent pool for ARVs [33] that may hold the key for access to affordable newer ARVs in the future. This concept was originally mooted by the MSF, along with Essential Inventions to the UNITAID board in June 2006 to overcome the difficulties to access newer ARVs. As Ellen t'Hoen of 
Table 6. Data on Drug Licensing of Originator Companies to Non-U.S. Countries

\begin{tabular}{|c|c|c|c|c|}
\hline S. No. & $\begin{array}{l}\text { Patent } \\
\text { Holder }\end{array}$ & Drug & Non US Companies Licensed & India \\
\hline 1 & GSK & $\begin{array}{l}\text { lamivudine, zidovudine and } \\
\text { lamivudine + zidovudine }\end{array}$ & $\begin{array}{l}\text { Cipla Medpro - the third largest generic drug } \\
\text { company in South Africa; Biotech Laboratories - a } \\
\text { subsidiary of Afrika Biopharma to supply generic } \\
\text { antiretrovirals to both the public and private sectors } \\
\text { throughout sub-Saharan Africa; Feza Pharmaceuticals, } \\
\text { Thembalami Pharmaceuticals and Aspen Pharmacare } \\
\text { South Africa, and Cosmos Limited in Kenya [1 \& 2] }\end{array}$ & NIL \\
\hline 2 & Tibotec & darunavir (Prezista) & Aspen Pharmacare, South Africa [3] & Emcure Pharmaceuticals Ltd, India \\
\hline 3 & BMS & atazanavir (Reyataz) & Aspen Pharmacare, South Africa [4] & Emcure Pharmaceuticals Ltd, India \\
\hline 4 & BMS & stavudine and didanosine & $\begin{array}{c}\text { Aurobindo Pharma, in } 49 \text { countries including South } \\
\text { Africa [5] }\end{array}$ & Aurobindo Pharma, India \\
\hline 5 & Gilead & tenofovir DF & Aspen Pharmacare, South Africa [6] & $\begin{array}{c}\text { Emcure Pharmaceuticals Ltd., Hetero } \\
\text { Drugs Ltd., Strides Arcolab Ltd, Alkem } \\
\text { Laboratories } \\
\text { Aurobindo Pharma FDC, JB Chemicals } \\
\text { \& Pharmaceuticals, Matrix, Medchem } \\
\text { International, Ranbaxy, Shasun } \\
\text { Chemicals \& Drugs }\end{array}$ \\
\hline 6 & Gilead & $\begin{array}{l}\text { tenofovir disoproxil } \\
\text { fumarate and emtricitabine }\end{array}$ & $\begin{array}{c}\text { Aspen Pharmacare, South Africa, sold in } 95 \\
\text { developing countries [7 \& 8] }\end{array}$ & $\begin{array}{c}\text { *Licensing information not available; } \\
\text { Company manufacturing;Matrix } \\
\text { Laboratories, Aurobindo }\end{array}$ \\
\hline 7 & Pfizer & delavirdine & $\begin{array}{l}\text { not-for-profit group the Concept Foundation and the } \\
\text { International Dispensary Association, Thailand [9] }\end{array}$ & NIL \\
\hline 8 & Merck & efavirenz & Aspen Pharmacare, South Africa [10] & $\begin{array}{c}\text { *Licensing information not available; } \\
\text { Company manufacturing; Aurobindo, } \\
\text { Cipla Limited, Strides Arcolab, Matrix } \\
\text { Laboratories, Emcure Pharmaceuticals, } \\
\text { Hetero Drugs }\end{array}$ \\
\hline 9 & $\begin{array}{l}\text { GSK \& } \\
\text { BI }\end{array}$ & $\begin{array}{l}\text { lamivudine }+ \text { stavudine }+ \\
\text { nevirapine (Triomune) }\end{array}$ & $\begin{array}{l}\text { Enaleni Pharmaceuticals, a subsidiary of Indian } \\
\text { generic drugs manufacturer Cipla, South Africa [11] }\end{array}$ & NIL \\
\hline 10 & BI & nevirapine & Aspen Pharmacare, South Africa [12] & $\begin{array}{l}\text { *Licensing information not available; } \\
\text { Company manufacturing; Ranbaxy, } \\
\text { Aurobindo, Cipla, Strides Arcolabs, } \\
\text { Hetero Drugs, Matrix Laboratories }\end{array}$ \\
\hline
\end{tabular}

1. www.thebodypro.com/content/art11014.html - 20k -

2. http://www.empowermentsa.co.za/betalk.php?myid=27

3. http://www.tibotec.com/bgdisplay.jhtml?itemname=dw_leftblock1

4. www.medicalnewstoday.com/articles/38017.php - 59k

5. www.haiafrica.org/index.php?option $=$ com content\&task=view\&id=105\&Itemid=1 - 31k

6. http://www.gilead.com/access_partnerships

7. http://investors.gilead.com/phoenix.zhtml?c=69964\&p=irol-newsArticle \&ID=700521\&highlight

8. http://www.aegis.com/NEWS/BW/2005/BW050411.html

9. http://www.thebodypro.com/content/art11680.html

10. www.medicalnewstoday.com/articles/27787.php - 53k

11. http://icommons.org/article print/a-sick-state-access-to-medicine-in-south-africa

12. http://www.essentialdrugs.org/edrug/archive/200312/msg00017.php

the UNITAIDS explains [34]: "A patent pool is a mechanism whereby patent owners put their patents in a 'pool' and allow others who need access to those patents to use them in exchange for a royalty payment. Patent pools have, in fact, been used to drive forward innovation in many different fields of technology, for example in the development of recording equipment, where you need multiple patents to be able to produce a certain product". Hoen considers that the patent pooling as a strategy will not only help the development of new fixed-dose combination drugs that combine multiple compounds into one pill, especially for the newer drugs and in developing fixed-dose combinations or paediatric formulations [34].

The advantages of patent pool appear to be huge. Like, for example, the development of pediatric formulations or the much-needed FDCs for less toxic first and second-line treatments. Patent filed by originator companies on individual compounds typically hamper the development of FDCs, a barrier that a patent pool would help break. Generic versions of new drugs also could be developed quickly through the patent pool as the generic companies need not wait for the 20-year patent expiration. If the patent pool is accessed by multiple companies, the resultant competition 
should drive down the price, as seen for the current first line ARVs. What is more, these drugs could be exported to poor countries with HIV/AIDS load that have no manufacturing capability by countries like India, Brazil and Thailand. All these could be built into the licensing agreements with the originator companies that own the patents. But this can become successful only if the patent owning companies are willing to put their patents into the pool. Efforts are on at the UNITAID to work out the modalities of operating the proposed patent pool. In fact the recently concluded WHO Global Strategy and Plan of Action on Public Health, Innovation and Intellectual Property of the InterGovernmental Working Group on Public Health and Innovation [35] had recommended exploring the feasibility of patent pools for diseases of the poor [36]. By the end of 2009 , the UNITAID pool is eventually expected to run as a separate entity [37].

The need for affordable ARVs to vulnerable sections of society like children, pregnant women and people with HIVTB in resource-poor countries cannot be overemphasized. The urgency is especially for the paediatric populations as, of the 22 ARVs approved by the US FDA for adults, as many as 8 are not approved for use in children while 9 do not have any pediatric formulations [38].

\section{CONTRIBUTORSHIP}

Kanikaram Satyanarayana conceived, designed and wrote the article.

Sadhana Srivastava shared in the draft preparation and participated in overall interpretation, revision and finalization of the paper.

\section{ACKNOWLEDGEMENT}

We thank Mr Yogesh Kumar and Ms Sheeba Chawla, IPR Unit, ICMR for assistance in the preparation of the paper.

\section{REFERENCES}

[1] HIV sentinel surveillance and HIV estimations 2007 a technical brief \& HIV Burden In India. Available from: www.naco online.org/upload/Publication/M\&E\%20Surveillance,\%20Research /HIV\%20Sentinel\%20Surveillance\%20and\%20HIV\%20Estimation $\% 202007$ A\%20Technical\%20Brief.pdf (accessed July 2009).

[2] Available from: http://www.nacoonline.org/upload/Documents/ List $\% 20$ of $\% 20127 \% 20$ ART $\% 20$ centres\% 20with\%20addresses.pdf (accessed July 2009).

[3] Antiretroviral Therapy Guidelines for HIV-Infected Adults and Adolescents Including Post-exposure Prophylaxis. (New Delhi, India National AIDS Control Organization), 2007. Available from: www.nacoonline.org/upload/documents/Antiretroviral\%20therapy $\% 20$ guidelines $\% 20$ for $\% 20 \%$ HIVinfected $\% 20$ adults $\% 20$ adolescent s\%20including\%20including\%20post-exposure.pdf. (accessed July 2009).

[4] Available from: http://infochangeindia.org/200811287509/Health/ News/HIV-prevalence-down-in-high-risk-states-but-up-in-lowrisk-ones.html. (accessed July 2009).

[5] Highly Active Antiretroviral Therapy-HAART. Available from: http://www.sfaf.org/beta/2009_win/haartchar (accessed August 2009).

[6] Overview of HIV and AIDS in India. Available from: www.avert. org. (Last updated March 09, 2009).

[7] Electronic Orange Book. Available from: http://www.fda.gov/cder/ ob/default.htm (Last updated 2009).

[8] Available from: www.fda.gov/bbs/topics/news/2007/new01677. html. (accessed August 2009).
[9] Available from: www.fda.gov/bbs/topics/NEWS/2007/NEW017 26.html (accessed July 2009).

[10] USFDA: HIV prevalence data\President's Emergency Plan for AIDS Relief . Available from: www.fda.gov/oia/pepfar.html (Last updated May 14, 2009).

[11] Prioritizing Second-Line Antiretroviral Drugs for Adults and Adolescents: a Public Health Approach (First \& Second Line). Available from: www.who.int/hiv/pub/meetingreports/second line art report 2008.pdf. (accessed July 2009).

[12] Available from: www.nacoonline.org/upload/Divisions/CST/ ART\% 20Rollout-\%20Dec\%2008.xls. (accessed August 2009).

[13] Available from: www.nacoonline.org/National_AIDS_Control_ Program/PEP_full/ (accessed August 2009).

[14] HIV prevelance dataUUSFDA Approved HIV AIDS Drug. Available from: http://www.fda.gov/oashi/aids/virals.html (updated January, 2008).

[15] WHO, UNAIDS, UNICEF. Towards Universal Access - Scaling up priority HIV/AIDS interventions in the health sector - Progress Report (Geneva, World Health Organization), 2008. Available from: http://www.who.int/hiv/mediacentre/universal access prog ress_report_en.pdf (accessed July 2009).

[16] Medicine Sans Frontiers (MSF). Running in Place: Too Many Patients Still in Urgent Need of HIV/AIDS Treatment. Medecins Sans Frontieres (MSF) Briefing Document on HIV/AIDS. XVII International AIDS Conference 3-8 August 2008, Mexico City.

[17] Boulle A, Orrell C, Kaplan R, et al. Substitutions due to antiretroviral toxicity or contraindication in the first 3 years of antiretroviral therapy in a large South African cohort. Antivir Ther 2007; 12: 753-60.

[18] World Health Organization. Antiretroviral therapy for HIV infection in adults and adolescents: recommendations for a public health approach. (Geneva, World Health Organization), 2006 revision.

[19] Agreement on Trade-Related Aspects of Intellectual Property Rights Annex 1C, Art. $70 \S 8$ (entered into force 1994). Available from: http://www.wto.org/english/tratop_e/trips_e/t_agm2_e.htm. (accessed August 2009).

[20] Dionisio D, Messeri D. Impending flop for brand antiretrovirals in the emerging markets? Open AIDS J 2008; 2: 68-71.

[21] Satyanarayana K. TRIPS, patents \& HIV/AIDS drugs. Indian J Med Res 2005; 121: 211-14. Available from: http://www.icmr.nic. in/ijmr/2005/april/editorial2.pdf (accessed July 2009).

[22] Diane V, Havlir VD, Hammer SM. Patents versus patients? antiretroviral therapy in India. N Engl J Med 2005; 353: 749-51.

[23] Pujades-Rodríguez M, O’Brien D, Humblet P, Calmy A. Secondline antiretroviral therapy in resource-limited settings: the experience of Médecins Sans Frontières. AIDS 2008; 22: 1305-12.

[24] Gilead Licenses Viread to Eight Generic Companies. Available from: http://www.redorbit.com/news/health/670013/gilead_licenses viread to eight generic companies/index.html (accessed July 2009).

[25] Kivela J, O'Brien D, Mills C, Sabapathy K. The price of change replacing stavudine with tenofovir in first-line ART in scaling-up settings. XVII International AIDS Conference 3-8 August 2008, Mexico City. Available from: http://www.doctorswithoutborders. org/events/symposiums/2008-aids-iac/assets/files/MSF-MexicoIAC-Briefing-Document.pdf (accessed July 2009)

[26] NGO Files Pre-Grant Opposition against Anti-HIV Drug, Combivir. Available from: http://www.bio-medicine.org/medicinenews/NGO-Files-Pre-Grant-Opposition-Against-Anti-HIV-DrugCombivir-8908-1/ (accessed August 2009).

[27] GSK Withdraws Combivir Patent Application from India and Thailand. Available from: http://www.twnside.org.sg/title2/intellec tual_property/info.service/twn\%20ipr\%20info\%20090603/090603. doc (accessed August 2009).

[28] Abbott Labs' bid for anti-HIV drug patent to face stiff challenge. Available from: http://www.livemint.com/2007/08/27001549/ Abbott-Labs8217-bid-for-ant.html?d=1 (accessed July 2009).

[29] Doha WTO Ministerial 2001: Ministrial Declaration. Available from: http://www.wto.org/english/thewto_e/minist_e/min01_e/min decle.htm (accessed July 2009).

[30] Satyanarayana K, Srivastava S. Poverty, health \& intellectual property rights with special reference to India. Indian J Med Res 2007; 126: 390-406. Available from: http://www.icmr.nic.in/ijmr/ 2007/october/1016.pdf 
[31] Satyanarayana K. Towards equitable health care: drug prices, and beyond. Indian J Med Res 2008; 127: 301-4.

[32] Why are AIDS drugs unaffordable in India? Available from: http://infochangeindia.org/200801086828/Agenda/HIV/AIDS-BigQuestions/Why-are-AIDS-drugs-unaffordable-in-India.html (accessed August 2009).

[33] UNITAID moves towards a patent pool for medicines [press release]. UNITAID, Geneva, 9 July 2008. Available from: http://www.unitaid.eu/en/20080709113/News/UNITAID-movestowards-a-patent-pool-for-medicines.html (accessed July 2009).

[34] t' Hoen E. How a 'Patent Pool' Could Help Solve the Access to Medicines Crisis. Available from: http://www.msfaccess.org/media -room/press-releases/msf-welcomes-unitaid-patent-pool-endorseme nt/ (accessed August 2009).
[35] Global Strategy and plan of action on public health, innovation and intellectual property. 61st World Health Assembly WHA 61.21 24 May 2008. Available from: http://www.who.int/gb/ebwha/pdf_ files/A61/A61_R21-en.pdf (accessed July 2009).

[36] Satyanarayana $\bar{K}$. The Inter-Governmental Working Group on Public Health, Innovation and Intellectual Property (IGWG) - The way ahead. Indian J Med Res 2008:128: 577-80. Available from: http://www. icmr.nic.in/ijmr/2008/november/editorial4.pdf (accessed August 2009).

[37] Sukkar E. Patent pools: an idea whose time has come. BMJ 2009; 338: b1630.

[38] Untangling the Web of ARV Price Reductions, 11 th edition. MSF, July 2008. Available from: http://www.msfaccess.org/main/hivaids/untangling-the-web-of-antiretroviral-price-reductions-11 thedition/ (accessed July 2009).

(c) Satyanarayana and Srivastava; Licensee Bentham Open.

This is an open access article licensed under the terms of the Creative Commons Attribution Non-Commercial License (http://creativecommons.org/licenses/by-nc/ 3.0/) which permits unrestricted, non-commercial use, distribution and reproduction in any medium, provided the work is properly cited. 